\title{
A cost variation analysis study of various bisphosphonates preparations available in the Indian market
}

\author{
Sushma V. Naidu ${ }^{1 *}$, Vibha Rani ${ }^{2}$ \\ ${ }^{1}$ Department of Pharmacology, Oxford Medical College, Hospital and Research Centre, Bangalore, Karnataka, India \\ ${ }^{2}$ Department of Pharmacology, Malla Reddy Medical College for Women, Hyderabad, Telangana, India
}

Received: 27 November 2019

Accepted: 08 January 2020

\section{*Correspondence:}

Dr. Sushma V. Naidu,

Email: drsushma23@gmail.com

Copyright: $(\odot$ the author(s), publisher and licensee Medip Academy. This is an open-access article distributed under the terms of the Creative Commons Attribution Non-Commercial License, which permits unrestricted non-commercial use, distribution, and reproduction in any medium, provided the original work is properly cited.

\begin{abstract}
Background: Osteoporosis is a chronic disease leading to weakened and porous bones which increases the risk of fractures. It is a treatable condition using drugs like bisphosphonates. There is wide variation in the cost among various brands of bisphosphonates in the Indian market, so the objective of the study was to analyse cost of different brands of bisphosphonates.

Methods: Cost of both oral and injectable bisphosphonates in the same strength and dosage forms was obtained from CIMS India (January-April 2019). For oral form of the drug, price was calculated per 10 tablets, for injectable form the price per ampoule or vial was calculated and cost ratio, percentage of cost variation was calculated.

Results: 15 different formulations of bisphosphonates were analyzed and it was found that cost ratio is found to be highest with $60 \mathrm{mg}$ of pamidronate injection and lowest with $10 \mathrm{mg}$ alendronate tablet, also pamidronate $60 \mathrm{mg}$ injection has highest percentage of cost variation (9632\%) and lowest cost variation is seen with $10 \mathrm{mg}$ alendronate $(35 \%)$. Cost ratio of 11 formulations was found to be very high which was $>2$ while percentage of cost variation of 11 formulations was found to be more 100 .

Conclusions: This study concludes that there is wide variation in cost of various brands of bisphosphonates in India. The huge price variation creates unnecessary burden leading on the patients resulting in noncompliance which increases the risk of morbidity and mortality. Therefore, there is an urgent need to regulate the cost of various formulations of bisphosphonates which will reduce the financial burden on the patients.
\end{abstract}

Keywords: Bisphosphonates, Cost ratio, Cost variation, Essential medicines, Pharmacoeconomics, Price variation

\section{INTRODUCTION}

Osteoporosis is a metabolic disease characterized by structural deterioration of bone tissue, low density of bones leading to fragility of bones with porous bones which increases the risk of fractures. ${ }^{1}$ World Health Organization (WHO) has defined osteoporosis as bone mineral density that lies 2.5 standard deviations or more below the average value for young healthy women. The various risk factors for osteoporosis include calcium deficiency, vitamin D deficiency, long term use of corticosteroids, prolonged use of anticoagulants, inadequate physical activity, excessive thinness, alcohol, smoking, organ transplant, history of fractures and postmenopausal women. ${ }^{2}$ Genetic factors also play a key role and the genes involved are OPG, RANK and RANKL. ${ }^{3}$ It is a silent disease affecting the bones of spine, hip, wrist and shoulders. The diagnosis is made by measuring the bone mineral density by means of dual Xray absorptiometry (DXA). ${ }^{4}$ WHO states that, following cardiovascular disease, osteoporosis is second global health problem and according to it, one out of three women and one out of eight men in India are affected by it. ${ }^{5}$ The prevention and treatment of osteoporosis includes 
good diet, regular intake of calcium with vitamin D, weight bearing with muscle strengthening exercises and pharmacological treatment which includes estrogen, teriparatide, denosumab, selective estradiol receptor modulator (SERM) and the antiresorptive drugs called bisphosphonates. ${ }^{6}$ The various bisphosphonates available are etidronate, tiludronate, pamidronate, zolendronate, risedronate and alendronate. These bisphosphonates which are pyrophosphate analogues act by inhibiting the activity of osteoclasts either by promoting their apoptosis or by inhibiting the components of cholesterol biosynthetic pathway. Their adverse effects mainly include heart burn, oesophageal irritation, abdominal pain, diarrhoea and rarely osteonecrosis of the jaw. ${ }^{7}$

The prices of drugs in India are fixed, controlled and monitored by National Pharmaceutical Pricing Authority (NPPA) and the Government of India issued the Drugs Prices Control Order (DPCO) in 1995 to regulate the prices of drugs. ${ }^{8}$ The DPCO 2013 contains 680 scheduled drug formulations spread across 27 therapeutic groups which are price controlled. ${ }^{9}$ Currently Indian markets is plethora of branded drugs for every drug molecule with huge price variation among different brands of same formulations. ${ }^{10}$ Frequently, doctors and pharmacists promote branded drugs and these drugs are sold at very higher prices than their generic version. As a result Indian consumers have to suffer the high cost of these branded drugs as most of the people lack insurance along with inadequate government funding due to which patients pay from out of pocket for drugs. ${ }^{11}$

Pharmacoeconomics is the analysis of the cost of drug therapy and its benefits to the health care system. ${ }^{12}$ A cost variation analysis study will help doctors to prescribe the right drug for the patient as we have numerous brands of Bisphosphonates available in the market. Therefore, this study was carried out to compare the cost of different brands of Bisphosphonates that are available in the Indian market.

\section{METHODS}

The cost of oral and injectable bisphosphonates which are available in the Indian market was noted from CIMS India January- April 2019 (Source: CIMS, DrugsUpdate and Medline).

Bisphosphonates available in the oral form are alendronate, risedronate, ibandronate and injectable forms are zolendronate, pamidronate, ibandronate.

The cost of a bisphosphonate in the same strength and form which are manufactured by different pharmaceutical companies was taken down

For oral form of the drug, price was calculated per 10 tablets and for injectable form the price per ampoule or vial was calculated. All prices were calculated in Indian rupees.
Fixed-dose combinations of bisphosphonates, two or more drugs from the same company in the same strength or form was excluded from the study.

The cost ratio was calculated by using the formula:

$$
\text { Cost ratio }=\frac{\text { Price of most expensive brand }}{\text { Price of least expensive brand }}
$$

The difference in the maximum and minimum price of the same drug formulation was calculated. The percentage variation in cost was calculated using the formula:

Cost variation $(\%)=$

Price of most expensive brand - Price of least expensive brand $\times 100$ Price of least expensive brand

Based on percentage variation, the prices of all the drugs were divided into 5 groups as follows:

- Group 1: $<24.99 \%$

- Group 2: $25-49.99 \%$

- Group 3: 50-99.99\%

- Group 4: 100-499.99\%

- Group 5: $>500 \%$.

\section{RESULTS}

In the study prices of 5 bisphosphonates available in 15 different formulations was analyzed and it was found that there was wide variation in their prices.

Table 1 shows price variation of various formulations of bisphosphonates. Pamidronate, zolendronate is only available as injectable form and risedronate, alendronate is only available in the tablet form while ibandronate is available in both tablet and injectable form. Pamidronate, alendronate and ibandronate is found to be available with maximum i.e. 4 formulations and risedronate is available in only in 1 formulation i.e. tablet $35 \mathrm{mg}$. Among all the bisphosphonates, cost ratio is found to be highest with 60 $\mathrm{mg}$ of pamidronate injection and lowest with $10 \mathrm{mg}$ alendronate tablet, also pamidronate $60 \mathrm{mg}$ injection has highest percentage of cost variation $(9632 \%)$ and lowest cost variation is seen with $10 \mathrm{mg}$ alendronate (35\%). Cost ratio of 11 formulations of bisphosphonates was found to be very high which was $>2$ while percentage of cost variation of 11 formulations was found to be more than 100 and 3 formulation had percentage of cost variation of more than 1000 .

In alendronate percentage of cost variation was found to be highest in $5 \mathrm{mg}$ tablet (123.3\%) and lowest with $10 \mathrm{mg}$ tablet $(35 \%)$. Injectable zolendronate is available in 2 formulations and highest cost variation is found in $5 \mathrm{mg}$ injection (798.1\%) and lowest in $4 \mathrm{mg}$ injection (137.9\%). In pamidronate, lowest cost variation is found with $90 \mathrm{mg}$ injection (190\%) and highest is found with $60 \mathrm{mg}$ injection $(9632 \%)$. Highest cost variation is found with $150 \mathrm{mg}$ tablet $(8043.7 \%)$ of ibandronate and lowest is 
seen with $3 \mathrm{mg}$ injectable form (66.6\%). Ibandronate is manufactured by 19 pharmaceutical companies, zolendronate by 18 companies, pamidronate by 12,8 companies produce alendronate and least with risedronate i.e. 6 .

Table 1: Price variation of various bisphosphonates preparations.

\begin{tabular}{|c|c|c|c|c|c|c|c|}
\hline Drugs & Form & $\begin{array}{l}\text { Dose (in } \\
\text { mg) }\end{array}$ & $\begin{array}{l}\text { No. of } \\
\text { brands }\end{array}$ & $\begin{array}{l}\text { Minimum } \\
\text { price (INR)* }\end{array}$ & $\begin{array}{l}\text { Maximum price } \\
\text { (INR)* }\end{array}$ & Cost ratio & $\begin{array}{l}\text { Cost variation } \\
(\%)\end{array}$ \\
\hline \multirow[t]{4}{*}{ Alendronate } & Tablet & 5 & 2 & 30 & 67 & 2.2 & 123.3 \\
\hline & Tablet & 10 & 5 & 40 & 54 & 1.35 & 35 \\
\hline & Tablet & 35 & 3 & 150 & 265 & 1.7 & 76.6 \\
\hline & Tablet & 70 & 6 & 245 & 440 & 1.7 & 79.5 \\
\hline Residronate & Tablet & 35 & 6 & 11 & 695 & 63.1 & 6218.1 \\
\hline \multirow[t]{2}{*}{ Zolendronate } & Injection & 4 & 13 & 1350 & 3212 & 2.3 & 137.9 \\
\hline & Injection & 5 & 5 & 2173 & 19516 & 8.9 & 798.1 \\
\hline \multirow[t]{4}{*}{ Pamidronate } & Injection & 15 & 2 & 579 & 2579 & 4.4 & 345.4 \\
\hline & Injection & 30 & 12 & 158 & 4112 & 26 & 2502.5 \\
\hline & Injection & 60 & 8 & 106 & 10316 & 97.3 & 9632 \\
\hline & Injection & 90 & 6 & 1800 & 5220 & 2.9 & 190 \\
\hline \multirow[t]{4}{*}{ Ibandronate } & Tablet & 50 & 3 & 150 & 1310 & 8.7 & 773.3 \\
\hline & Tablet & 150 & 11 & 167 & 13600 & 81.4 & 8043.7 \\
\hline & Injection & 3 & 3 & 1200 & 2000 & 1.6 & 66.6 \\
\hline & Injection & 6 & 4 & 2630 & 13950 & 5.3 & 430.4 \\
\hline
\end{tabular}

*INR- Indian National Rupee.

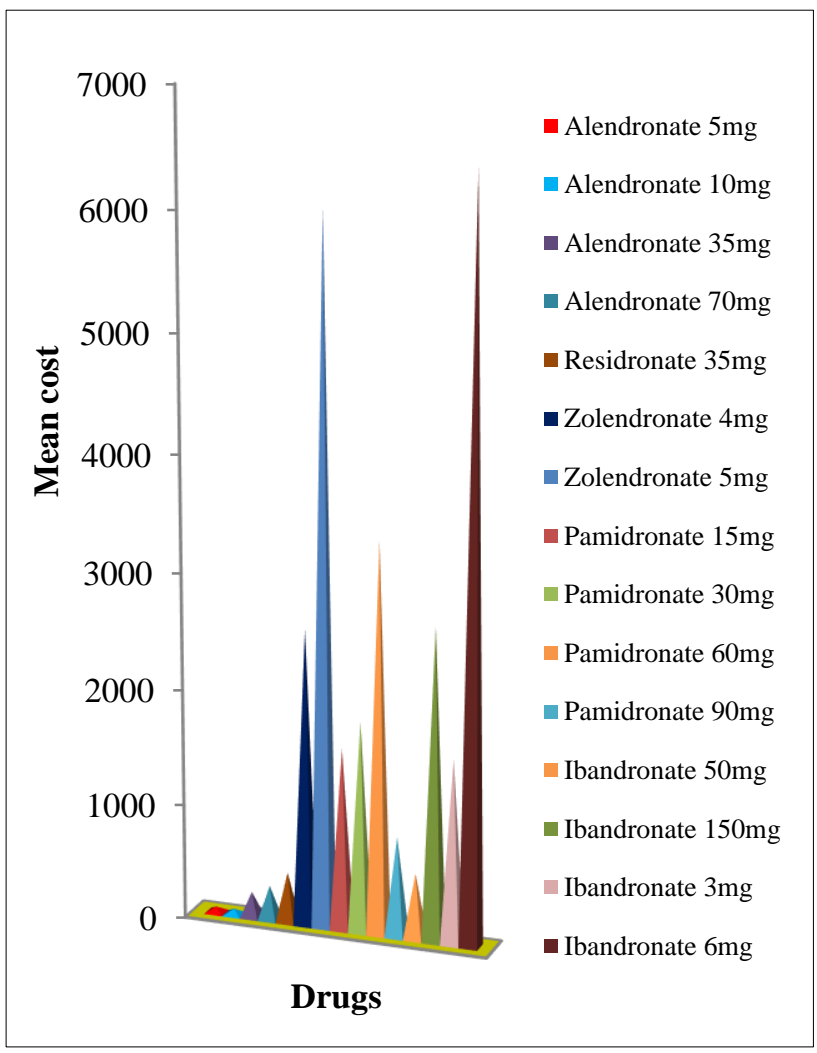

Figure 1: Mean cost of various formulations of bisphosphonates.

Figure 1 shows the mean cost of bisphosphonates and it is highest for ibandronate (6 mg Inj) and lowest for $5 \mathrm{mg}$ tablet of aledronate.
Table 2 shows classification of bisphosphonates based on percentage of price variation and it was highest in group 5 with 6 formulations while it was nil in group 1 .

Table 2: Classification of bisphosphonates based on percentage of price variation and numbers of formulations.

\begin{tabular}{|lll|}
\hline Groups & $\begin{array}{l}\text { Price variation of } \\
\text { bisphosphonates }(\%)\end{array}$ & $\begin{array}{l}\text { No. of } \\
\text { formulations }\end{array}$ \\
\hline Group 1 & $<24.99$ & Nil \\
\hline Group 2 & $25-49.99$ & 1 \\
\hline Group 3 & $50-99.99$ & 3 \\
\hline Group 4 & $100-499.99$ & 5 \\
\hline Group 5 & $>500$ & 6 \\
\hline
\end{tabular}

\section{DISCUSSION}

According to WHO, essential medicines is defined as those that satisfy the priority health care needs of the $p$ population. ${ }^{13}$ It is considered to be one of the cost effective component of our health care system. ${ }^{14}$ Based on the reports by WHO $68 \%$ of Indian population lack access to Essential medicines. ${ }^{1}$ The main objective of the study was identifying minimum and maximum percentage of price variation among the different brands of bisphosphonates available in the Indian market and this pharmacoeconomics study reveals that there is huge price variation among various formulations of bisphosphonates.

Osteoporosis is a chronic disease which results in significant morbidity, mortality and bisphosphonates needs to be given on long term basis to the patients. The 
huge price variation of bisphosphonates will cause economic burden to the patients and also decreases patient compliance. The reason for huge price variation among drugs is the cost spent by pharmaceutical industries on drug research with development, market segmentation, patent protection and competition between pharmaceutical companies. ${ }^{15}$ Generic drugs are cheaper than branded drugs and the Government of India has made it mandatory for the drugs to be sold in generic names rather than trade names. The main drawbacks for use of generic drugs in India are lack of standard assurance on quality of generic drugs, availability of branded generic drugs, high commission given to pharmacists or doctors by pharmaceutical companies for promoting branded drugs. ${ }^{16}$ In our study the cost ratio of few drugs is more than 50 which is similar to study done on antifungals. ${ }^{17}$ The percentage of cost variation of some drugs in our study is more than 500 which is also similar to study done on antifungals, gastric acid suppressants, proton pump inhibitors, antipsychotics, non-steroidal anti-inflammatory drugs. ${ }^{17-21}$

Out-of-pocket payments (OOPs) are defined as nonreimbursable payments made by individuals to health care providers at the time using service without involvement of third party. This leads to severe financial strain on the patients leading to medication nonadherence by patients. ${ }^{22}$ According to WHO, OOPs can be reduced by removing user fees in public health facilities, giving exemption to vulnerable section like pregnant women with children. ${ }^{23}$ Doctors as wells as patients have doubts regarding the quality of generic drugs sold. To overcome this, awareness has to be made on the generic equivalents of medicine, generic drug stores needs to keep evidence based results on the quality of generic drugs and all essential medicines needs to be kept in generic stores. ${ }^{24}$ Pharmacoeconomic studies needs to be carried out regularly as it is very helpful for health care officials, policy makers in rational prescribing of drugs, individual patient treatment and allocation of resources. ${ }^{25}$

\section{CONCLUSION}

Study concludes that there is wide variation in cost of various brands of bisphosphonates in India. NPPA should strictly control the prices of drugs and use of generic drugs must be encouraged by the doctors. Pharmacoeconomics must be taught as a part of medical curriculum to undergraduates as well as post graduate students and importance of generic drugs, rational prescribing of drugs, essential medicines must be taught. There needs to be coordinated efforts of regulatory authorities, doctors, pharmacists, pharmaceutical companies, government organizations with general public to tackle this problem of huge price variation of drugs.

Funding: No funding sources Conflict of interest: None declared Ethical approval: Not required

\section{REFERENCES}

1. Christodoulou C, Cooper C. What is osteoporosis?. Postgrad Med J. 2003;79(929):133-8.

2. World Health Organization: Risk factorsOsteoporosis. Available at: https://www.who.int/chp/topics/Osteoporosis.pdf. Assessed on 13 September 2019.

3. Kumar V, Kabbas A, Fausto N, Aster JC. Bones, Joints and Soft tissue tumours. In: Robins and Cotran Pathologic Basis of Diseases. 8th edition. Philadelphia: Elsevier Inc; 2010: 1205-1256.

4. Sözen T, Özışık L, Başaran NÇ. An overview and management of osteoporosis. Europ J Rheumatol. 2017;4(1):46-56.

5. Shaki O, Rai SK, Kashid M, Chakrabarty BK. Prevalence of osteoporosis in peri-and postmenopausal women in slum area of Mumbai, India. $\mathbf{J}$ Mid-Life Health. 2018;9(3):117-22.

6. Nallasivan S. Current treatment of osteoporosis. Indian J Rheumatol. 2019;14:57-60.

7. Bruton L, Chabner BA, Knollman BC. Agents Affecting Mineral Ion Homeostasis and Bone turnover. In: Goodman and Gilmans The Pharmacological Basis of Therapeutics. 12th edition. China: Mc Graw Hill Companies; 2011: 1275-1306.

8. Narula S. Current Drug Pricing Status in India. Pharmacoeconomics. 2015;1(1): e101.

9. Drug Price Control Order. Available at: http://www.arthapedia.in/index.php? Assessed on 15 September 2019.

10. Das SC. A critical study on availability and price variation between different brands: Impact on access to medicines. Ind J Pharmaceut Sci. 2007;69(1):1603.

11. Selvaraj S, Farooqui HH, Karan A. Quantifying the financial burden of households' out-of-pocket payments on medicines in India: a repeated crosssectional analysis of National Sample Survey data, 1994-2014. BMJ Open. 2018;8(5):e018020.

12. Satoskar RS, Rege NN, Tripathi RK, Bhandarkar SD. General considerations and Pharmacokinetics. In: Pharmacology and Pharmacotherapeutics. 25th ed. India: RELX India Pvt Ltd. Popular Prakashan; 2017: 3-29.

13. Tripati KD. Introduction, Routes of Drug Administration. In: Essentials of Medical Pharmacology. 7th Edition. New Delhi: Jaypee Brothers Medical Publishers Ltd.; 2013: 4-5.

14. Maiti R, Bhatia V, Padhy BM, Hota D. Essential medicines: an Indian perspective. Ind J Commu Med: Offic Publicat Ind Assoc Prevent Soc Med. 2015;40(4):223-32.

15. Roy V, Rewari S. Ambiguous drug pricing: a physician's dilemma. Ind $\mathrm{J}$ Pharmacol. 1998;30(6):404-7.

16. Galani VJ. Choice of better medicine in India: Branded vs Generic Medicine. Pharmacy Pharmacol Intl J. 2017;5:1-2. 
17. Tiwari A, Reddy P, Goyal C. Cost analysis of antifungal drugs available in India: A pharmacoeconomic perspective. Indian J Pharm Pharm. 2016;3:192-6.

18. Sharmada Nerlekar AR, Karia S, Desousa A. Comparing prices of commonly used gastric acid suppressants available in India. Asian J Pharm Clin Res. 2016;9(4):378-80.

19. Chandra A, Kumar M, Kumar L, Dikshit H. Cost variation analysis of proton pump inhibitors available in Indian market. Int $\mathbf{J}$ Basic Clin Pharmacol. 2018;7(8):1626-29.

20. Shah NP, Chincholkar AS, Wagh RJ, Siddiqui WA. Cost variation analysis of antipsychotic drugs available in Indian market: An economic perspective. Int J Basic Clin Pharmacol. 2017;6:684-8.

21. Patel BS, Chavda FM, Mundhava SG. Cost variation analysis of single nonsteroidal anti-inflammatory agents available in Indian market: An economic perspective. Inter J Pharma Sci Res. 2016;7(5):217480.
22. Shet N, Qadiri GJ, Kalal BS, Sunita Saldanha. Impact of Out-Of-Pocket Health Care Financing and Health Insurance Utilization among the Population: A Systematic Review. Int J Health Sci Res. 2018;8(2):249-57.

23. Out-of-pocket payments, user fees and catastrophic expenditure. Available at: https://www.who.int/health_financing/topics/financia 1-protection/out-of-pocket-payments/en/. Accessed on 16 September 2019.

24. Kotwani A. Commentary: Will generic drug stores improve access to essential medicines for the poor in India?. J Public Health Policy. 2010;31(2):178-84.

25. Kumar S, Baldi A. Pharmacoeconomics: Principles, methods and economic evaluation of drug therapies. Ph Tech Med. 2013;2(5):362-9.

Cite this article as: Naidu SV, Rani V. A cost variation analysis study of various bisphosphonates preparations available in the Indian market. Int J Basic Clin Pharmacol 2020;9:436-40. 